\title{
Çin’deki Türkoloji Çalışmaları
}

\section{Turcology Studies in China}

\author{
Zhixing Shen ${ }^{1}$ (D), Ömer Faruk Işsk ${ }^{1}$ (])
}

'Zhejiang Uluslararası Çalıșmalar Üniversitesi, Doğu Dilleri ve Kültürleri Fakültesi, Türkçe Bölümü, Zhejiang, Çin

ORCID: Z.S. 0000-0002-3212-0942

Ö.F.I. 0000-0002-3773-4089

Sorumlu yazar/Corresponding author: Ömer Faruk Işık,

Zhejiang Uluslararası Çalışmalar Üniversitesi, Doğu Dilleri ve Kültürleri Fakültesi, Türkçe

Bölümü, Zhejiang, Çin

E-mail: omerfarukisik@zisu.edu.cn

Bașvuru/Submitted: 01.07.2020

Revizyon Talebi/Revision Requested: 02.09.2020 Son Revizyon/Last Revision Received: 12.09 .2020 Kabul/Accepted: 27.10 .2020

Atıf/Citation:

Shen, Z. \& Isik, O. F. (2020). Çin'deki Türkoloji Çalışmaları. TUDED 60(2), 587-608. https://doi.org/10.26650/TUDED2020-0046

\section{ÖZET}

Çinliler ve Türkler arasındaki ilişki tarihin çok eski dönemlerine dayanmaktadır. Bu nedenle iki millet arasında kurulan bağlar her zaman birbiri için önemli olmuştur. Günümüzde de bu bağ önemini korumaktadır. İki milletin çağımızdaki birer temsilcisi olan Çin Halk Cumhuriyeti ve Türkiye Cumhuriyeti arasındaki diplomatik ilişkiler 1971 yılında başlamıştır. Bu zamandan günümüze değin iki ülke arasındaki iş birliğine dayalı ilişkinin gün geçtikçe arttığı görülmektedir. Gelişen siyasi ve ekonomik ilişkilere bağlı olarak Çin'de yürütülen Türkoloji çalışmalarının güncel durumunu ortaya koymak bu araștırmanın amacını olușturmaktadır. Bu bağlamda Çin'de yürütülen Türkoloji çalışmaları; Türkoloji bölümü bulunan üniversiteler, Türkçeden Çinceye çevrilen edebi eserler, Türkçe öğretimi üzerine yazılan kitaplar, Türkçe üzerine yazılmış makale ve tezler bağlamında incelenmiştir. Yapılan incelemeler neticesinde Çin'de yürütülen son dönem Türkoloji çalışmalarının iki ülke arasındaki diğer gelişmelere bağlı olarak günden güne geliştiği görülmektedir. Fakat çalışmaların gelişmesine rağmen; alanda yetişmiş akademisyen, yazılmış ders kitapları, yayımlanmış makale ve tezler bakımından çalışmaların yeterli olgunluğa erişmemiş olduğu görülmektedir. Ayrıca Türkçeden Çinceye çevrilen edebi eserlerin de çok dar bir yelpazeye sahip olduğu, çeviri çalışmalarının özellikle bir yazarın eserlerinde yoğunlaştığı tespit edilmiştir. Bu çalışma ile Çin'de yürütülen Türkoloji çalışmalarının bilinirliğinin artırılması beklenmektedir. Ayrıca çalışmanın, Türkoloji üzerine Çin bağlamında çalışmalar yürüten/yürütmek isteyen araştırmacılara katkı sağlaması öngörülmektedir.

Anahtar Kelimeler: Türkoloji, Türklük bilimi, Çin, Türkçe öğretimi, Türk-Çin ilişkileri

\section{ABSTRACT}

The Turkish-Chinese relationship dates to ancient times and the official relations between the People's Republic of China and the Republic of Turkey were established in 1971. Since then, the co-operation between them has been gradually increasing. This study thus investigates the current status of Turcology studies in China depending on the developing political and economic relations between them. Literary works of universities with Turcology departments were examined and included translations from Turkish to Chinese, Turkish teaching books, articles and theses written in Turkish. The study results indicated that the recent Turcology studies in China have been considerably developing, following other developments between them; however, despite the progress, studies have not reached sufficient maturity in terms of written textbooks and published articles and theses. It has also been observed that literary works translated from Turkish to Chinese have a narrow spectrum, and they are concentrated particularly in the works of Orhan Pamuk.

Keywords: Turcology, China, Turkish studies, Turkish teaching, Turkish-Chinese relations 


\section{EXTENDED ABSTRACT}

The state of Turcology studies in China has been an unexplored topic at present. Turcology is defined as a branch of science that investigates Turkish history, literature, language, folklore, and scientific research (TDK, 2005). In this study, the recent Turcology studies in China were examined by compiling and analyzing literary works of universities with Turcology departments such as translations from Turkish to Chinese, Turkish teaching books, articles and theses written in Turkish.

Turcology studies in China were first established in 1985 when a Turkish department was opened at Beijing International Studies University; in the past 35 years, the number of Turcology departments in China has reached 12. Notably, the opening of new departments has been occurring in parallel with the developments in diplomatic and economic relations between them. The examination of Turcology departments according to yearly intervals revealed that only one department existed in 1985-2000, two in 2000-2010, and 12 in 2010-2019. The recent opening of many Turcology departments demonstrated an interest in the Turkish language and culture in China, but it also showed that most departments have not reached an academic maturity. The establishment of business associations of Turcology sections in China with relevant institutions in Turkey would contribute to the maturation, as academic scholars and students would strengthen the bond with Turkey.

The Turcology departments in Chinese universities require trained academic staff. Currently, only one university professor and three associate professors exist at two universities. In all, 33 of the 37 academic staff across China work as lecturers or assistants. The academic aspects of the departments will be strengthened by encouraging the assistants and faculty members in the departments to pursue academic studies. The implementation of academic personnel exchange programs with universities and institutions in Turkey can also contribute to this field.

Since 1985, more than 316 students have graduated from the departments of Turcology, and 255 students are actively continuing their studies. In the coming years, a significant increase in the number of students studying in the departments of Turcology and graduating from these departments will occur. Projects for these departments can be implemented by the relevant ministries and universities in Turkey to disseminate knowledge about Turkey and contribute to Turcology.

Since 1971, only 25 Turkish works have been translated into Chinese, and 13 of these works belong to Orhan Pamuk. This aspect indicates that Turkey's written resources have not been recognized or received attention in China. Supporting translation and promoting studies of Turkish literature by Turkey will contribute to the development of cultural relations between the two countries.

Another indicator of the academic deficiency in the departments of Turcology is that Turkish teaching resources used in the departments of Turcology are not sufficient, and a lack 
of resources in some skill areas is also observed. Moreover, Turkish history, literature, culture, art, community life, and Ottoman Turkish resources written in Chinese are also lacking; the Turcology department students would benefit significantly from such resources. Although resources are prepared by the efforts of experts in this field, the resource shortage can be promptly resolved with the support provided by the relevant institutions and universities from Turkey in line with the needs to be determined.

One of the academic indicators is undoubtedly the number of masters and doctoral thesis. The number of articles written in Turkish in China since 1971 is 48 . The subject-wise distribution of the articles written is not found. Furthermore, a number of masters and doctoral theses are at a low level compared to the number of departments.

Turkey is developing rapidly, and the relationship between China is progressing based on the recent past. The rapid development of the relations has enabled some figures to increase rapidly in terms of quantity, but qualitative developments have not followed digital changes. Therefore, co-operation between Turkey and universities in China and the development of relations between academics will contribute to the qualitative improvement needed in this area. Likewise, the support and qualitative contributions to the Turcology studies in China with the projects to be implemented by the relevant Turkish government institutions, such as Yunus Emre Institute, Presidency of Turks Abroad and Relative Communities, Turkish Cooperation and Coordination Agency, will significantly improve the field. Moreover, the support of Turcology in China by Turkey would indirectly contribute to its “One Belt One Road” project. 


\section{GIRIŞ}

Kadim iki komşu olan Türkler ve Çinliler tarih boyunca ilişki içerisinde olmuşlardır. Bu ilişki kimi zaman ticarete, kimi zaman savaşa-barışa, kimi zaman da akrabalığa dayanmıştır. İki millet arasında tarihin derinliklerinde yaşanan ilişkiler günümüzde özellikle yazılı kaynaklar aracılığıyla net bir şekilde görülebilmektedir. Yıllıklar ve devlet adamlarının biyografisi niteliğindeki Çin kaynakları Türk tarihi ile ilgili bilgi veren ilk kaynaklardandır. Örneğin, Çin kaynaklarında Türk isminin ilk kez kullanıldığı kaynak 542 tarihine dayanmaktadır. Zhou Hanedanlığı dönemine ait bu kaynakta o yıllarda Türklerle olan ilişkiden bahsedilmiştir (Linghu, 2011). Bu bilgiden hareketle iki millet arasındaki ilişkilerin en az 1478 yıl öncesine dayandığını söylemek mümkündür. Aynı şekilde Muharrem Ergin de yaklaşık 1300 yıl önce yazılan Orhun Abidelerinde, Çin ilişkilerine önemli bir yer ayrıldığı hatta Kül Tigin ve Bilge Kağan kitabelerinin batı cephelerinin Çince yazıldığını belirtmektedir. Ayrıca Kül Tigin abidesinin ve türbesinin yapımında Türk ve Çinli sanatkârlar birlikte çalışmıştır (Ergin, 2011). İnan (2017) ve Buran (2019) ise Çinlilerin Türklerin adet ve ananelerini, dini telakkilerini daha milattan önceki devirlerde öğrendiklerini, Türklerin yaşam tarzlarıyla ilgili eski Çin kaynaklarında birçok bilgi bulunduğunu belirtmektedirler. Tarihin derinliklerine dayanan ilişkilerin bir yansımasını da dil bilimi çalışmalarında görmek mümkündür. İnayet (2006) yaptığı bir çalışmasında Türkçenin Çinceye doğrudan veya dolaylı olarak 348 kelime verdiğini belirtmektedir. Yine Karaağaç (2015) tarafından yapılan bir çalışmada da Türkçeden Çinceye verilen 218 kelime olduğu görülmektedir. İki milletin de tarihi kaynaklarında bir diğerini önemli bir şekilde konu edinmesi ve dil anlamındaki etkileşim Türkler ve Çinliler arasındaki ilişkinin önemine işaret etmektedir.

İlk ilişkilerin üzerinden geçen zamanla birlikte özellikle Türk milletinin yaşadığı coğrafya genişlediğinden dolayı kimi Türk devletleri ile Çin arasında komşuluk kalmamıştır fakat bu durum ilişkilerin bitmesi anlamına da gelmemiştir. Özellikle tarihi ticaret yolları Çin ve Türk devletleri arasında sürekli köprü vazifesi görmüştür. 20.yy’a gelindiğinde iki milletin bünyesinden Türkiye Cumhuriyeti ve Çin Halk Cumhuriyeti gibi iki önemli devlet meydana gelmiştir. Kökleri çok eski tarihlere dayanan bu iki devletin günümüzdeki ilişkisi, geçmişte olduğundan daha uzak ve önemsiz değildir. Kuruluşlarından bu yana ilişkilerinin incelenmesi ve mevcut durumun ortaya konulması gelecekteki ilişkilerin iki ülkenin menfaatine uygun olarak inşa edilmesi bakımından önem teşkil etmektedir.

Türkiye Cumhuriyeti Dışişleri Bakanlığının açık kaynaklarından hareketle iki ülke arasındaki ilişki özetlenecek olursa, Türkiye ile Çin Halk Cumhuriyeti arasındaki diplomatik ilişkilerin 1971 yılında başladığı görülmektedir. Her iki ülkenin de ekonomik ve siyasi olarak dışa açılımlarının hızlandığ 1 1980'li yıllarda iki ülke arasındaki iş birliklerinin önceki döneme göre arttığı görülmüştür. 2010 yılında iki ülke arasındaki ilişkiler "stratejik iş birliği" düzeyine yükseltilmiştir. 2000'li yıllarda ilk kez 1 milyar doları bulan ticaret hacmi 2019 yılında 21 milyar dolara ulaşmıştır. Çin, Türkiye'nin en büyük 3. ticaret ortağı konumundadır. Yine son 10 yıllık dönemde cumhurbaşkanı, başbakan ve hükümetler arası ziyaretlerin ve 
ikili anlaşmaların önceki dönemlere göre yoğunlaştığı görülmektedir. Bu yoğunluğa turizm açısından bakılacak olunursa Türkiye'deki Çinli turist hareketliliğinin 2002 yılında başladığ 1 görülmektedir. 2018 yılının “Çin’de Türkiye Turizm Yılı” ilan edilmesiyle bir önceki yıla göre turist sayısı da \%60 oranında artarak 390.000 rakamına ulaşmıştır. 2019 yılında ise bu sayı 427.000 olmuştur (Türkiye Cumhuriyeti Dışişleri Bakanlığı, 2020). Gelecek yıllarda Çin'den Türkiye'ye gelen turist sayısının daha da artacağı ön görülmektedir (BİK, 2019; Duran, 2019). Yaşanan tüm siyasi ve ekonomik gelişmeler iki ülkenin birbiri için öneminin giderek arttı̆̆ını göstermektedir.

İki ülke arasındaki eğitim alanındaki etkileşimler incelendiğinde yine diplomatik ve ekonomik ilişkilerin etkisi görülecektir. Türkiye Cumhuriyetinin ilk Şanghay Konsolosu olan, 36 yıldır kesintisiz olarak Çin'de yaşayan ve Çin'de yüksek lisans mezunu ilk Türk öğrencilerden biri olan Noyan RONA'dan edinilen bilgilere göre iki ülke arasındaki öğrenci hareketliliği ilk kez 1980'li yıllarda gerçekleşmiştir. İki ülke arasında imzalanan kültürel değişim anlaşmasında lisans eğitimini tamamlamış 5'er öğrenciye her yıl karşılıklı olarak yüksek lisans bursu verilmesi kararlaştırılmıştır. Milli Eğitim Bakanlıklarınca seçilip gönderilen öğrencilerin eğitim, konaklama ve burs giderleri eğitim gördükleri ülke tarafından karşılanmış ancak öğrencilerin yol masrafı karşılanan giderlere dâhil edilmemiştir. Bu program kapsamında Türkiye ilk kez 1981 yılında Çin’e bir öğrenci gönderirken Çinli öğrenciler de ilk kez aynı tarihte Türkiye'ye gelmişlerdir. 1990'lı yılların ortasına kadar Türkiye'de bu programdan sadece Sinoloji bölümü öğrencilerinin yararlandığ 1 görülmektedir. 1990’lı yılların ortasından sonra diğer bölüm öğrencileri de programa kabul edilmiştir. Ancak RONA'ya göre öğrencilerin yol masraflarının karşılanmaması, uzaklık ve burs tutarının yetersiz kalması gibi sebeplerden ötürü burs programı Türk öğrenciler arasında pek ilgi görmemiştir.

Çin tarafından gelen öğrencilerin durumuna bakıldığında 1985 yılından önce Çin’deki üniversitelerde müstakil bir Türkoloji bölümü bulunmadığından dolayı Türkiye'ye gönderilen öğrenciler genellikle Çin'de uluslararası ilişkiler bölümünü bitiren öğrenciler olmuştur. Kültürel değişim programının dışında ilk kez 1985 yılında bütün masrafların Çin hükümeti tarafından karşılanmasıyla, 10 Çinli öğrenci lisans eğitimi almaları amacıyla Türkiye’ye gönderilmiştir. Ankara Üniversitesinde eğitim gören bu öğrencilerin 7'si Türk Dili ve Edebiyatı bölümünde 1'i Tarih bölümünde 1'i ise İletişim bölümünde olmak üzere toplam 9 öğrenci lisans eğitimlerini Türkiye'de tamamlamıştır. Öğrencilerin 1'i lisans eğitimine başlamadan Türkçe öğrendiği ilk ay ülkesine dönüş yapmıştır.

Günümüzde hem Türkiye hem de Çin'de yükseköğretim kademesinde uluslararası öğrenci olarak eğitim almak diplomatik ilişkilerin ilk başladığı yıllara nazaran oldukça kolaydır. Öğrenciler kendi imkânları ile öğrenim görebilecekleri gibi başvurabilecekleri hükümet ya da üniversite burs programlarına da erişme firsatı yakalamaktadır. Bununla birlikte üniversiteler arası iş birliği anlaşmaları ile ilgili bölümler arasında öğrenci değişim programları da bir diğer seçenek olarak ortaya çıkmaktadır. Fakat eskiye nazaran şartların 
çok daha müsait olmasına rağmen günümüzde halen Türk öğrencilerin Çin'de, Çinli öğrencilerin de Türkiye' de eğitimi öncelikli olarak tercih etmediği öğrenci hareketliliğine dair istatistiklerde görülmektedir (YÖK, 2020 ve Ministry of Education The People's Republic of China, 2020).

İki ülke arasında değinilmesi gereken bir diğer konu da Türkiye'de yürütülen Sinoloji çalışmaları ile Çin'de yürütülen Türkoloji çalışmalarıdır. Türkiye'de ilk Sinoloji bölümü Ankara Üniversitesi Dil Tarih Coğrafya Fakültesi bünyesinde 1935 y1lında Atatürk'ün talimatı ile Türk tarihi araştırmalarının derinleştirilmesi amacıyla açılmıştır (Ankara Üniversitesi, 2017). Günümüzde YÖK'e bağl1 6 üniversitede "Sinoloji”, "Çin Dili ve Edebiyatı” ve "Çince Mütercim Tercümanlık” bölümlerinden biri bulunmaktadır (YÖK, 2019). Son yıllarda Türkiye ve Çin arasında üniversiteler arası iş birliklerinin arttığı gözlemlenmektedir. Bu bilgilerden hareketle Türkiye'de Sinoloji üzerine ilginin arttığı söylenebilir. Ancak bu noktada eleştirel bakış açıları da mevcuttur. Sarıtaş (2011), Türkiye'de yürütülen Sinoloji çalışmalarının 85 yıl önce başlamış olmasına rağmen yeterli, planlı ve nitelikli olmadığını belirtmektedir. Demircan ve Özdemir (2019) ise Türkiye'de Çin üzerine yapılan akademik çalışmaları inceledikleri araştırmada son yıllarda çalışmaların artmasına rağmen bu çalışmaların yeterli seviyede olmadığ 1 yorumunda bulunmuşlardır.

Türkiye'de yapılan Sinoloji çalışmalarına karşılık Çin'de yürütülen Türkoloji çalışmalarının durumu ise yakın zamanda araştırılmamış bir konu olarak karşımıza çıkmaktadır. Türkoloji, diğer bir değişle Türklük bilimi; Türk dili, tarihi, edebiyatı ve halk bilimi araştırmalarını konu edinen bilim dalı olarak tanımlanmaktadır (TDK, 2005). Bir diğer tanımı ile Türkoloji; Türk kavimlerinin -bütün şümuliyle- dil, tarih, edebiyat, etnografya ve folklorunu tetkik eden bir ilimdir (İnan, 2017). Bu anlamıyla düşünüldüğünde ilk Türkoloji kaynaklarının Çinlilere ait olduğunu söylemek mümkündür. Öyle ki İnan; Çinlilerin Türklerin adet ve ananelerini, dini telakkilerini daha milattan önceki devirlerde öğrendiklerini, Türklerin yaşam tarzlarıyla ilgili eski Çin kaynaklarında birçok bilgi bulunduğunu belirtmektedir (İnan, 2017). Buran da ilk Türkoloji çalışmalarının bir yönüyle Sinoloji çalışmalarının bünyesinde başladığını, 16. yüzyıldaki Sinoloji araştırmaları ile Orta Asya Türklerinin dil ve tarihleriyle ilgili bilgilerin ortaya çıktığını ve bu araştırmaların Türkoloji’nin gelişmesine katkı sağladığını belirtmektedir (Buran, 2019).

Türkoloji’yi çok geniş bir coğrafyada ve tüm Türk dilleriyle birlikte ele almak gerekmektedir. Fakat bu çalışmada yalnızca Türkiye ve Türkiye Türkçesi üzerine yapılan çalışmalar incelenmiştir. Araştırmanın bu şekilde sınırlandırılmasının başlıca sebebi Çin'deki akademik çalışmalarda Türkoloji alanına dâhil edilebilecek ülkelerin ve Türk dillerinin ayrı ayrı ele alınmasından kaynaklanmaktadır. Çalışmanın diğer sınırlılıkları da Türkiye ve Çin Halk Cumhuriyeti arasında diplomatik ilişkilerin başlangıç tarihi olan 1971 yılından günümüze kadarki zaman dilimine ve Çin anakarasındaki çalışmalara odaklanmış olmasıdır. 


\section{Araştırmanın Amacı}

Bu araştırmanın amacı Çin'de Türkoloji faaliyetlerine dair yapılan çalışmaları tespit etmek ve Çin bağlamında Türkoloji üzerine çalışacak akademisyenlere katkıda bulunmaktır. Bu amaçla Çin'deki Türkoloji faaliyetlerinin güncel durumu aşağıdaki başlıklar üzerinden incelenecektir.
a. Türkoloji bölümü bulunan üniversiteler,
b. Türkoloji bölümlerinin öğrenci sayısı,
c. Türkoloji bölümlerinin akademisyen sayısı,
d. Türkçeden Çinceye çevrilen edebi eserler,
e. Türkçe öğretimi üzerine yazılan kitaplar,
f. Türkçe üzerine yazılan lisansüstü tezler,
g. Türkçe üzerine yazılan makalelerin güncel durumu nedir?

\section{YÖNTEM}

\section{Araştırmanın Modeli}

Nitel bir çalışma olan araştırmada Çin'deki Türkoloji çalışmalarının tespit ve tasnif edilmesi amacıyla durum tespit çalışması yapılmıştır. Yıldırım ve Şimşek'e (2013) göre nitel durum çalışmalarının en önemli özelliği bir ya da birkaç durumun derinlemesine araştırılması ile bu duruma ilişkin etkenlere etraflı bir şekilde odaklanabilmektir. Bu çalışmada Çin'de akademik anlamda Türkoloji üzerine yapılan çalışmalar tespit edilmek istenmiş, bu bağlamda 7 ayrı başlıkta durum ele alınmıştır.

\section{Verilerin Toplanması}

Üniversitelerde bulunan Türkoloji bölümlerine ilişkin bütün verilere (kuruluş yılı, aktifmezun öğrenci sayısı, akademisyen sayısı, vb.) ilgili bölümlerde görevli akademisyenlerle yapılan görüşmelerin sonucunda ulaşılmıştır. Türkçeden Çinceye çevrilen edebi eserler, Türkçe öğretimi üzerine yazılan kitaplar, Türkçe ile ilgili yüksek lisans ile doktora tezleri ve Türkçe üzerine yazılan makalelere ilişkin veriler ise doküman incelemesi ile tespit edilmiş olup internet ortamında ilgili mecralar taranarak kaynaklara ulaşılmıştır. Ayrıca tarihi süreci daha iyi aydınlatabilmek amacıyla Çin ve Türkiye arasındaki ilişkilerin ilk gelişmeye başladığ süreçte uluslararası öğrenci olarak Çin'de ve Türkiye'de bulunan iki kişinin tecrübelerine yer verilmiştir. 


\section{BULGULAR VE YORUM}

a. Türkoloji bölümü bulunan üniversitelere dair bulgular;

Tablo 1: Çin'de bulunan Türkoloji bölümlerine dair temel bilgiler

\begin{tabular}{|c|l|l|l|c|}
\hline No & Üniversite & Fakülte & Bölüm & $\begin{array}{c}\text { Açıldığı } \\
\text { Tarih }\end{array}$ \\
\hline $\mathbf{1}$ & $\begin{array}{l}\text { Beijing (Pekin) Uluslararası Çalışmalar } \\
\text { Üniversitesi }\end{array}$ & Asya-Afrika Dilleri Fakültesi & Türkçe & 1985 \\
\hline $\mathbf{2}$ & Çin İletişim Üniversitesi & Yabancı Diller Fakültesi & Türkçe & 2001 \\
\hline $\mathbf{3}$ & $\begin{array}{l}\text { Şanghay Uluslararası Çalışmalar } \\
\text { Üniversitesi }\end{array}$ & Doğu Dil ve Kültürleri Fakültesi & Türkçe & 2011 \\
\hline $\mathbf{4}$ & Xi`an Uluslararası Çalışmalar Üniversitesi & Doğu Dil ve Kültürleri Fakültesi & Türkçe & 2012 \\
\hline $\mathbf{5}$ & Guangdong Yabancı Diller Üniveristesi & $\begin{array}{l}\text { Asya ve Afrika Dilleri ve Kültürleri } \\
\text { Fakültesi }\end{array}$ & Türk Dili ve & 2016 \\
\hline $\mathbf{6}$ & Xinjiang Eğitim Enstitüsü* & Çift Yabancı Dil Yüksekokulu & Türkçe & 2016 \\
\hline $\mathbf{7}$ & Tianjin Uluslararası Çalışmalar Üniversitesi & Doğu Dil ve Kültürleri Fakültesi & Türkçe & 2017 \\
\hline $\mathbf{8}$ & Pekin İkinci Yabancı Dil Üniversitesi & Asya ve Afrika Dilleri ve Kültürleri & Türkçe & 2017 \\
\hline $\mathbf{9}$ & Pekin Dil ve Kültür Üniversitesi & Fakültesi & & 2018 \\
\hline $\mathbf{1 0}$ & $\begin{array}{l}\text { Zhejiang Uluslararası Çalışmalar } \\
\text { Üniversitesi }\end{array}$ & Doğu Dil ve Kültürleri Fakültesi & Türkçe & 2018 \\
\hline $\mathbf{1 1}$ & $\begin{array}{l}\text { Zhejiang Yuexiu Yabancı Diller } \\
\text { Üniversitesi }\end{array}$ & Doğu Dil ve Kültürleri Fakültesi & Türkçe & 2019 \\
\hline $\mathbf{1 2}$ & $\begin{array}{l}\text { Sichuan Uluslararası Çalışmalar } \\
\text { Üniversitesi }\end{array}$ & Evrensel Olmayan Diller Fakültesi & Türkçe & 2019 \\
\hline
\end{tabular}

Tablo 1 incelendiğinde Çin'de bir üniversite bünyesinde açılan ilk bölümün 1985 yılında Pekin Uluslararası Çalışmalar Üniversitesi, Asya-Afrika Dilleri Fakültesinde açıldı̆̆ görülmektedir. Aynı yıl Çin hükümetinin Türkiye'ye eğitim amaçlı gönderdiği öğrenciler ve bölümün açıldığı tarihin öncesinde iki ülke arasında uygulanan kültürel değişim programı düşünüldüğünde 1980'li yıllar itibariyle Çin'in Türkiye ile ilişkilerine katkı sağlayacak somut adımlar attığı söylenebilir. Fakat 1985 yılında açılan ilk bölüm, uzun yıllar boyunca ülkenin Türkoloji üzerine çalışan tek bölümü olmuştur.

2000'li yıllara gelindiğinde iki ülke arasında ticaret hacminin tarihte ilk kez 1 milyar dolar seviyesine ulaştığı (Türkiye Cumhuriyeti Dışişleri Bakanlığı, 2020) ve Türkiye'de Çinli turist hareketliliğinin yine bu yıllarda başladığı görülmektedir. Bu gelişmeler iki ülke arasındaki ilişkilerin geliştiğine işaret etmektedir. Yaşanan sosyal ve ekonomik gelişmelere paralel olarak 16 yıl sonra 2001 yılında Çin İletişim Üniversitesi bünyesinde Türkoloji üzerine çalışacak ikinci bölüm açılmış ve aynı yıl öğrenci alımına başlamıştır.

2010 yılında iki ülke arasındaki ilişkiler "stratejik işbirliğgi” düzeyine yükseltilmiştir. Diplomatik ilişkilerin başladığı yıl olan 1971'den beri gelişen ilişkiler 2010 yılı ile güçlü bir ivme kazanmıştır. Geçen 9 yıllık süre içerisinde gelişen ekonomik, sosyal ve diplomatik ilişkilerle birlikte Türkoloji çalışmaları da üniversitelerin bünyelerinde ciddi bir gelişim göstermiştir. Çin’de bulunan 13 Türkoloji bölümünden 11'i 2010-2019 yılları arasında açılmıştır. 
Yine Tablo 1'e bakıldığında bölümlerin 3'ünün Asya ve Afrika Dilleri ve Kültürleri Fakültesi bünyesinde; 5 'inin Doğu Dil ve Kültürler Fakültesi bünyesinde; 1 'inin Yabancı Diller Fakültesi bünyesinde; 1'inin Ortadoğu Fakültesi bünyesinde; 1'inin Evrensel Olmayan Diller Fakültesi bünyesinde; 1'inin ise Çift Yabancı Dil Yüksekokulu bünyesinde bulunduğu görülmektedir. Bölümlerin isimlerinin ise yalnız birinin Türk Dili ve Edebiyatı diğer 11'inin Türkçe bölümü olarak belirtildiği görülmektedir. İlgili bölümlerde Türkçe öğretiminin yanı sıra Türk tarihi, edebiyatı, ekonomisi ve sosyal hayatına yönelik çeşitli dersler verilmekte ayrıca çeviri bilim dersleri de bulunmaktadır. Bölümlerin ortak amacı; Türkçeye, Türk tarihine, edebiyatına, sosyal hayatına ve ekonomik yapısına hâkim Türkiye uzmanları yetiştirmektir.

b. Türkoloji bölümlerinin öğrenci sayısı

Tablo 2: Türkoloji Bölümlerinin Öğrenci Sayısı ve Öğrenci Alımlarına Dair Veriler

\begin{tabular}{|c|l|c|c|c|}
\hline No & \multicolumn{1}{|c|}{ Üniversite } & $\begin{array}{c}\text { Lisans } \\
\text { Öğrenci Sayısı }\end{array}$ & $\begin{array}{c}\text { Yüksek Lisans } \\
\text { Öğrenci Sayısı }\end{array}$ & $\begin{array}{c}\text { Öğrenci Kabul } \\
\text { Periyodu (Lisans) }\end{array}$ \\
\hline $\mathbf{1}$ & Pekin Uluslararası Çalışmalar Üniversitesi & 16 & 2 & 4 yılda bir \\
\hline $\mathbf{2}$ & Çin İletişim Üniversitesi & 16 & - & 4 yılda bir \\
\hline $\mathbf{3}$ & Şanghay Uluslararası Çalışmalar Üniversitesi & 11 & - & 4 yılda bir \\
\hline $\mathbf{4}$ & Xi`an Uluslararası Çalışmalar Üniversitesi & 69 & 2 & Her yıl \\
\hline $\mathbf{5}$ & Guangdong Yabancı Diller Üniveristesi & 24 & - & Her yıl \\
\hline $\mathbf{6}$ & Xinjiang Eğitim Enstitüsü & - & - & - \\
\hline $\mathbf{7}$ & Tianjin Yabancı Diller Üniversitesi & 11 & - & 4 yılda bir \\
\hline $\mathbf{8}$ & Pekin İkinci Yabancı Dil Üniversitesi & 31 & - & 2 yılda bir \\
\hline $\mathbf{9}$ & Pekin Dil ve Kültür Üniversitesi & 36 & - & 2 yılda bir \\
\hline $\mathbf{1 0}$ & Zhejiang Uluslararası Çalışmalar Üniversitesi & 20 & - & Her y1l \\
\hline $\mathbf{1 1}$ & Zhejiang Yuexiu Yabancı Diller Üniversitesi & 17 & - & Her y1l \\
\hline $\mathbf{1 2}$ & Sichuan Uluslararası Çalışmalar Üniversitesi & - & - & İki yılda bir \\
\hline & TOPLAM & 251 & 4 & - \\
\hline
\end{tabular}

Tablo 2 incelendiğinde Türkoloji bölümlerinde 2020 yılı rakamlarına göre 251 lisans, 4 yüksek lisans olmak üzere toplam 255 öğrenci bulunduğu görülmektedir. Aynı tabloda üniversitelerin öğrenci kabul periyotlarını görmek de mümkündür. Bu verilere göre üniversitelerin 4'ü her yıl; 4'ü 4 yılda bir; 3’ü de 2 yılda bir öğrenci kabul etmektedir. Xinjiang Eğitim Enstitüsü ise şu anda öğrenci kabul etmemektedir. Listede bulunan 12 üniversiteden 7'sinin son 5 yılda açıldığı göz önüne alındığında Türkoloji öğrenci sayısında ciddi bir artış yaşandığı ve yaşanacağı söylenebilir.

Tablo 3: Mezun Veren Üniversiteler ve Mezun Öğrenci Sayıları

\begin{tabular}{|l|l|c|c|}
\hline No & Üniversite & Dönem & Mezun Öğrenci Sayısı \\
\hline $\mathbf{1}$ & Pekin Uluslararası Çalışmalar Üniversitesi & 7 & +100 \\
\hline $\mathbf{2}$ & Çin İletişim Üniversitesi & 4 & +70 \\
\hline $\mathbf{3}$ & Şanghay Uluslararası Çalışmalar Üniversitesi & 2 & 21 \\
\hline $\mathbf{4}$ & Xìan Uluslararası Çalışmalar Üniversitesi & 4 & +100 \\
\hline $\mathbf{5}$ & Xinjiang Eğitim Enstitüsü & $\mathbf{1}$ & 25 \\
\hline \multicolumn{2}{r}{ TOPLAM } & - & +316 \\
\hline
\end{tabular}


Tablo 3 'te Türkoloji mezunu veren 5 üniversite görülmektedir. Bu üniversitelerden en fazla mezun veren üniversite 7 dönem ve 100'den fazla öğrenciyle Pekin Uluslararası Çalışmalar Üniversitesi'dir. Bunun ardından 4'er dönem mezun veren üniversiteler Çin İletişim Üniversitesi ve Xi'an Uluslararası Çalışmalar Üniversitesi'dir. 2011 yılında açılan Şanghay Uluslararası Çalışmalar Üniversitesi ise 2 dönemde 21 öğrenci mezun vermiştir. 2012 yılında açılan Xi'an Uluslararası Çalışmalar Üniversitesi'nin kendisinden önce açılan üniversiteler kadar mezun vermesinin sebebi her yıl öğrenci alması olarak gösterilebilir.

c. Türkoloji bölümlerinin akademisyen sayısı

Tablo 4: Türkoloji Bölümlerinin Akademik Personeline İlişkin Veriler

\begin{tabular}{|c|c|c|c|c|c|c|c|}
\hline No & Üniversite & Uyruk & Asistan & $\begin{array}{l}\text { Öğrr. } \\
\text { Görr. }\end{array}$ & $\begin{array}{l}\text { Doç. } \\
\text { Dr. }\end{array}$ & $\begin{array}{c}\text { Prof. } \\
\text { Dr. }\end{array}$ & Toplam \\
\hline 1 & Pekin Uluslararası Çalışmalar Üniversitesi & Türk 1 Çinli 3 & & 2 & 2 & & 4 \\
\hline 2 & Çin İletişim Üniversitesi & Türk - Çinli 2 & & 2 & & & 2 \\
\hline 3 & Şanghay Uluslararası Çalışmalar Üniversitesi & Türk 1 Çinli 3 & 1 & 2 & 1 & & 4 \\
\hline 4 & Xi`an Uluslararası Çalışmalar Üniversitesi & Türk 2 Çinli 4 & 2 & 4 & & & 6 \\
\hline 5 & Guangdong Yabancı Diller Üniveristesi & Türk 1 Çinli 3 & 3 & 1 & & & 4 \\
\hline 6 & Xinjiang Eğitim Enstitüsü & Türk - Çinli 2 & 1 & 1 & & & 2 \\
\hline 7 & Tianjin Yabancı Diller Üniversitesi & Türk - Çinli 2 & & 2 & & & 2 \\
\hline 8 & Pekin İkinci Yabancı Dil Üniversitesi & Türk 1 Çinli 1 & & 2 & & & 2 \\
\hline 9 & Pekin Dil ve Kültür Üniversitesi & Türk 1 Çinli 1 & 1 & 1 & & & 2 \\
\hline 10 & Zhejiang Uluslararası Çalışmalar Üniversitesi & Türk 1 Çinli 3 & 2 & 1 & & 1 & 4 \\
\hline 11 & Zhejiang Yuexiu Yabancı Diller Üniversitesi & Türk 1 Çinli 1 & 2 & & & & 2 \\
\hline 12 & Sichuan Uluslararası Çalışmalar Üniversitesi & Türk 1 Çinli 2 & 2 & 1 & & & 3 \\
\hline & TOPLAM & Türk 10 Çinli 27 & 14 & 19 & 3 & 1 & 37 \\
\hline
\end{tabular}

Tablo 4 incelendiğinde Türkoloji üzerine çalışan toplam 37 akademik personelin olduğu görülmektedir. 37 personel uyruklarına göre incelendiğinde dağılımın 10 Türk, 27 Çinli şeklinde olduğu görülmektedir. Akademisyenlerin büyük çoğunluğu doğal olarak Çinlidir. Bunun yanında üniversitelerin 9'unda Türk akademisyen bulunmaktadır. Bölümlerin büyük çoğunluğunda Türk akademisyenin bulunması öğrencilerin ana dili Türkçe olan akademisyenlerden ders alması bakımından önem teşkil etmektedir.

Akademisyenlerin unvanları incelendiğinde bütün bölümler arasında yalnız bir profesör ve 3 doçent unvanına sahip akademisyenin bulunduğu görülmektedir. Diğer akademisyenler çoğunlukla öğretim görevlisi ve asistan unvanlarında görev yapmaktadırlar. Bu veriler ışığında kısa sürede hızlı bir artış gösteren Türkoloji bölümlerinin doçent ve profesör unvanlarında öğretim üyesi ihtiyacının bulunduğu söylenebilir.

d. Türkçeden Çinceye çevrilen edebi eserler

Türkçe üzerine yapılan çalışmaların bir kolu olan edebi eserlerdeki çeviri çalışmaları iki ülke arasındaki ilişkinin bir göstergesidir. Bu başlık altında diplomatik ilişkilerin başladığ tarih olan 1971'den bu yana Çin'de çevirisi yapılmış edebi eserler incelenmiştir. 
Tablo 5: 1971 Sonrasında Türkçeden Çinceye Çevrilen Edebi ve Düşünsel Eserler

\begin{tabular}{|c|l|l|l|c|}
\hline No & Eserin Adı & Yazarı & Cevirmen(ler) & Cevrildiği Yıl \\
\hline $\mathbf{1}$ & İnce Memed & Yaşar Kemal & Li Xiande & 1981 \\
\hline $\mathbf{2}$ & Çalıkuşu & Reşat Nuri Güntekin & Xu Mei, Li Di & 1985 \\
\hline $\mathbf{3}$ & Benim Adım Kırmızı & Orhan Pamuk & Shen Zhixing & 2006 \\
\hline $\mathbf{4}$ & Beyaz Kale & Orhan Pamuk & Shen Zhixing & 2006 \\
\hline $\mathbf{5}$ & Kar & Orhan Pamuk & $\begin{array}{l}\text { Shen Zhixing, Zhang Lei, } \\
\text { Peng Jun, Ding Huijun }\end{array}$ & 2007 \\
\hline $\mathbf{6}$ & Resimli İstanbul-Hatıralar ve Şehir & Orhan Pamuk & He Peihua & 2007 \\
\hline $\mathbf{7}$ & Kara Kitap & Orhan Pamuk & Li Jiashan & 2007 \\
\hline $\mathbf{8}$ & Yeni Hayat & Orhan Pamuk & Cai Juanru & 2007 \\
\hline $\mathbf{9}$ & Sessiz Ev & Orhan Pamuk & Shen Zhixing, Peng Jun & 2008 \\
\hline $\mathbf{1 0}$ & Cevdet Bey ve Oğulları & Orhan Pamuk & Chen Zhubing & 2009 \\
\hline $\mathbf{1 1}$ & Huzur & Ahmet Hamdi Tanpınar & Xia Yongmin & 2009 \\
\hline $\mathbf{1 2}$ & Masumiyet Müzesi & Orhan Pamuk & Chen Zhubing & 2010 \\
\hline $\mathbf{1 3}$ & Yaban Bağcı & Ayşegül Özer & Shen Zhixing, Peng Jun & 2010 \\
\hline $\mathbf{1 4}$ & İstanbul'da Bir Merhamet Haftası & Murat Gülsoy & Xia Yongmin & 2010 \\
\hline $\mathbf{1 5}$ & Cemile & Orhan Kemal & Yin Tingting & 2011 \\
\hline $\mathbf{1 6}$ & Baba Evi & Orhan Kemal & Xia Yongmin & 2011 \\
\hline $\mathbf{1 7}$ & Saf ve Düşünceli Romancı & Orhan Pamuk & Peng Fasheng & 2012 \\
\hline $\mathbf{1 8}$ & İstanbul Bir Masaldı & Mario Levi & Chen Qing & 2014 \\
\hline $\mathbf{1 9}$ & Yeşil Peri Gecesi & Ayfer Tunç & Du Bo, Li Fan & 2014 \\
\hline $\mathbf{2 0}$ & Kafamda Bir Tuhaflık & Orhan Pamuk & Chen Zhubing & 2016 \\
\hline $\mathbf{2 1}$ & Karanlık Çökerken Neredeydiniz? & Mario Levi & Jiang Shan & 2016 \\
\hline $\mathbf{2 2}$ & Öteki Renkler & Orhan Pamuk & Zong Xiaofei, Lin Bianshui & 2018 \\
\hline $\mathbf{2 3}$ & Kırmızı Saçlı Kadın & Orhan Pamuk & Yin Tingting & 2018 \\
\hline $\mathbf{2 4}$ & Mutsuz Kedi Dila & Tulin Kozikoğlu & Zhang Di & 2018 \\
\hline $\mathbf{2 5}$ & Ben, Öteki ve Ötesi & İbrahim Kalın & Xia Yongmin, Tang Jiankun, & 2018 \\
\hline & & & Fan Xun, Chen Yan & \\
\hline
\end{tabular}

İki ülke arasındaki 49 yıllık geçmişte Çin Halk Cumhuriyetinde çevirisi yapılmış yalnız 25 Türkçe eser bulunmaktadır. Bunlar kronolojik olarak incelendiğinde Türkiye ve Çin arasındaki ilişkilere paralel seyrettiği görülmektedir. Çevirisi yapılan ilk kitap kültürel değişim programının başladığı 1981 yılına denk gelmektedir. Bu kitap Yaşar Kemal tarafından kaleme alınan Ince Memed isimli eserdir. Bu kitabın akabinde ikinci çeviri 1985 yılında yapılmıştır. 1985 yılından 2006 yılına kadar ise herhangi bir çeviri eser bulunmamaktadır. Türkoloji bölümlerinin son yıllardaki artışı gibi Türkçeden çevirisi yapılan kitap sayısı da 2000'li yıllarda artış göstermektedir. Bu artış gelecekte daha fazla Türkçe eserin Çinceye çevrileceğine işaret etmesi bakımından önemlidir.

Tablo 5 'te bulunan veriler incelendiğinde en çok Orhan Pamuk'un eserlerinin çevrildiği görülmektedir. Yazarın Nobel edebiyat ödülünü kazandığı yıl olan 2006 itibari ile yazara ait toplam 13 eser Çinceye çevrilmiştir. 2006-2015 yıları arasında Orhan Pamuk'a ait Benim Adım Kırmızı isimli eser Çin'de en fazla satan kitaplar listesinde yer almıştır. Yazar günümüzde Çinli okurlar arasındaki popülerliğini korumaktadır. Orhan Pamuk dışında birden çok eseri çevrilen yazarlar; ikişer eserle Orhan Kemal ve Mario Levi'dir. Bu verilerden hareketle Çin'de Türk 
edebiyatına yönelik ilginin yalnız yazar temelli olduğu ve herhangi bir Türk edebi akımına karşı ilginin bulunmadığı, Orhan Pamuk dışında birçok eseri Çinceye çevrilmiş Türk yazar olmadığı görülmektedir.

Türkçe eserleri Çinceye çeviren isimler incelendiğinde bir çeşitliliğin olduğu görülmektedir. Çevirisi yapılan 25 eserin çevrilmesinde 24 farklı isim emek vermiştir. Bu rakam Türkçeden Çinceye çeviri üzerine çalışan farklı isimlerin bulunduğunu göstermektedir.

\section{e. Türkçe öğretimi üzerine yazılan kitaplar}

Tablo 6: Çin'de Çinlilere Türkçe Öğretimi Üzerine Yazılan Kitaplar

\begin{tabular}{|c|c|c|c|}
\hline No & Eserin Adı & Yazar(lar)! & Yılı \\
\hline 1 & Türkçe 1 & Li Zhiyu, Zhou Zhengqing & 2004 \\
\hline 2 & Türkçe 2 & Li Zhiyu, Zhou Zhengqing & 2004 \\
\hline 3 & Güzel Türkçe Konuşalım & Liu Zhao, Li Zhiyu, Cem Aygün & 2005 \\
\hline 4 & Türkçe-Çince Sözlük. & Zhou Zhengqing, Zhou Yuntang & 2008 \\
\hline 5 & Türkçe Çeviri Pratikleri & Liu Zhao, Li Zhiyu & 2008 \\
\hline 6 & Türkçe Yazı ve Eserlerden Seçmeler & Gong Yingyuan & 2009 \\
\hline 7 & Pratik Türkçe Konuşma El Kitabı & Zuo Yunshan & 2011 \\
\hline 8 & Türkçe Dinleme ve Kelime Bilgisi Eğitimi & Dursun Köse & 2013 \\
\hline 9 & Türkçe-Çince Çeviri & Peng Jun, Ding Huijun. & 2014 \\
\hline 10 & Çağdaş Uygurca ile Türkçenin Mukayeseli Grameri & Maitireyimu-Shayiti & 2014 \\
\hline 11 & Pratik Türkçe-Çince El kitabı & Li Zhiyu, Liu Zhao, Cem Aygün & 2015 \\
\hline 12 & Türkçe Dil Bilgisi & Ding Huijun, Peng Jun & 2015 \\
\hline 13 & Türkçe-Çince Temel Askerlik Terimleri Sözlüğü & Jun Shi Yi Wen Yayın Evi & 2015 \\
\hline 14 & Türkçe-Çince Temel Diplomatik Terimler Sözlüğü & Jun Shi Yi Wen Yayın Evi & 2015 \\
\hline 15 & Türkçe-Çince Sadeleştirilmiş Sözlük & Jun Shi Yi Wen Yayın Evi & 2015 \\
\hline 16 & Temel Türkçe Dersleri 1 & Liu Zhao, Li Zhiyu, Cem Aygün & 2016 \\
\hline 17 & Temel Türkçe -İletişimsel bir yaklaşım 1 & Gong Yingyuan, Cao Yiqun & 2016 \\
\hline 18 & Türkçe Sesbilgisi Ders Kitabı & Zhang Lei. & 2016 \\
\hline 19 & Türkçe Konuşma Ders Kitabı & Ding Huijun, Peng Jun. & 2016 \\
\hline 20 & Türkçe Konuşma El Kitabı & Wei Zongling & 2016 \\
\hline 21 & Temel Türkçe Dersleri 2 & Liu Zhao, Li Zhiyu, Cem Aygün & 2017 \\
\hline 22 & Eski Türkçe Grameri & Liu Zhao & 2017 \\
\hline 23 & $\begin{array}{l}\text { Modern ve Çağdaş Türk Edebiyatı Eserlerinden } \\
\text { Seçmeler }\end{array}$ & Ding Huijun, Peng Jun & 2018 \\
\hline 24 & $\begin{array}{l}\text { Turistler İçin Konuşma-Sıfırdan Türkçe Konuşma } \\
\text { El Kitabı }\end{array}$ & Larousse Yayınevi & 2018 \\
\hline 25 & Türkçe Dil Bilgisi & Liu Zhao & 2019 \\
\hline 26 & Merhaba Türkçe & Han Zhimin, Chen Qing, Hacer Tokyürek & 2019 \\
\hline 27 & Türkçe Okuma Kitabı & Han Zhimin, Zhang Chao, Murat Elmalı & 2020 \\
\hline
\end{tabular}

Tablo 6' da Türkçe öğretimi üzerine yazılan ve bir bölümü Türkoloji bölümlerinde kullanılan 27 kitap görülmektedir. Eserler kategorik olarak incelendiğinde eserlerin 10'unun genel Türkçe öğretimi ve dil bilgisi; 6'sının konuşma; 4'ünün sözlük; 2'sinin çeviri; 2'sinin edebiyat, 1'erinin okuma, dinleme ve Eski Türkçe üzerine yayımlanmış eserler olduğu görülmektedir. Eserlerin büyük bir bölümünün Türkoloji öğrencilerinin ihtiyacına yönelik hazırlandığı bilinmektedir. 
Yine de listede "Turistler İçin Konuşma: Sıfırdan Türkçe Konuşma El Kitabı" ve "Pratik Türkçe Konuşma El Kitabı” gibi turizm amaçlı kaynakların olduğu da görülmektedir.

Genel Türkçe ve dil bilgisi öğretimine yönelik bir hayli kitap bulunmasına karşın bu kaynakların dört temel beceri alanını geliştirmek için yeterli olmadığı söylenebilir. Öyle ki genel Türkçe kitapları daha çok dil bilgisi öğretimine yoğunlaşmaktadır. Bu nedenle Türkçe öğretimi alanında eksik kalan beceri alanlarına yönelik her seviyede Çinli öğrencilerin ihtiyaçlarına cevap verecek nitelikte kitaplar bulunmamaktadır. Yine aynı şekilde Türkoloji bölümleri için; Osmanlı Türkçesi, Türk Tarihi, Türk Kültürü, Türk Toplumu, dönemlerine göre Türk Edebiyatı, edebi metin tahlilleri gibi konularda kaynakların bulunmaması da büyük bir eksiklik olarak değerlendirilebilir. Bu eksikliklere yönelik kaynakların oluşturulması Çin özelinde Türkoloji çalışmaları için önemli bir ihtiyaçtır.

f. Türkçe üzerine yazılan lisansüstü tezler

Tablo 7: Çin'de Türkçe Üzerine Yazılmış Lisansüstü Tezler

\begin{tabular}{|c|c|c|c|c|c|}
\hline No & Adı & Yazarı & Üniversitesi & Derecesi & Yilı \\
\hline 1 & $\begin{array}{l}\text { Basın Dillerinde Türkçe-Çince Sözcükler } \\
\text { ve Sözdizimini Karşlaştırma } \\
\text { 土耳其语汉语新闻词汇及句式特点对 } \\
\text { 比研究 }\end{array}$ & Ding Huijun & $\begin{array}{l}\text { Çin Halk Kurtuluş } \\
\text { Üniversitesi Yabancı } \\
\text { Dil Fakültesi }\end{array}$ & Y. Lisans & 2006 \\
\hline 2 & $\begin{array}{l}\text { Türkçe-Çince Gramerleri Karş1laştırma } \\
\text { 土耳其语汉语语法比较 }\end{array}$ & Elif Öner & $\begin{array}{l}\text { Huazhong Teknik } \\
\text { Üniversitesi }\end{array}$ & Y. Lisans & 2012 \\
\hline 3 & $\begin{array}{l}\text { Çince ve Türkçe Bağlaçları Karşılaştırma } \\
\text { 汉土连词对比 }\end{array}$ & Liu Tianwen & $\begin{array}{l}\text { Huazhong Teknik } \\
\text { Üniversitesi }\end{array}$ & Y. Lisans & 2012 \\
\hline 4 & $\begin{array}{l}\text { Çince Türkçe Fonetik Sistemlerini } \\
\text { Karş1laştırma } \\
\text { 汉土语音系统对比研究 }\end{array}$ & Li Xia & $\begin{array}{l}\text { Huazhong Teknik } \\
\text { Üniversitesi }\end{array}$ & Y. Lisans & 2012 \\
\hline 5 & $\begin{array}{l}\text { Türkçenin Zamansal Şekli ve Zamansal } \\
\text { Anlamı: Orhun'dan Eski Türk ve Kazak } \\
\text { Yazıtları ile Karş1laştırmalı Bir Çalışma } \\
\text { 突厥语时态形式与意义 : 鄂尔浑古突 } \\
\text { 厥和哈萨克碑铭比较研究 }\end{array}$ & Cem Aygün & $\begin{array}{l}\text { Çin Minzu } \\
\text { Üniversitesi }\end{array}$ & Y. Lisans & 2014 \\
\hline 6 & $\begin{array}{l}\text { Türkçe ve Çincedeki “bakmak" Fiillerini } \\
\text { Anlam Bakımından Karşılaştırma } \\
\text { 土汉动词 “看” 的义项分析及比较 }\end{array}$ & Aliye Altınkaya & $\begin{array}{l}\text { Şanhay Jiao Tong } \\
\text { Üniversitesi }\end{array}$ & Y. Lisans & 2015 \\
\hline 7 & $\begin{array}{l}\text { Çağdaş Uygurca ve Çağdaş Türkçe } \\
\text { Fiillerinin İsimleşmiş Şekillerini } \\
\text { Karş1laştırma } \\
\text { 现代维吾尔语与现代土耳其语动词的 } \\
\text { 静词化形式比较研究 }\end{array}$ & Abdulmicet Celili & $\begin{array}{l}\text { Çin Minzu } \\
\text { Üniversitesi }\end{array}$ & Y. Lisans & 2016 \\
\hline 8 & $\begin{array}{l}\text { Çağatay Uygurca ve Çăgdaş Türkçe } \\
\text { Fonksiyon Kelimelerini Karşılaştırma } \\
\text { 察合台维吾尔语与现代土耳其语虚词 } \\
\text { 的比较研究 }\end{array}$ & Zulayeti Dulikun & Xinjiang Üniversitesi & Y. Lisans & 2016 \\
\hline
\end{tabular}




\begin{tabular}{|c|c|c|c|c|c|}
\hline 9 & $\begin{array}{l}\text { Kırgızistan’daki Üniversite Öğrencilerinin } \\
\text { Çince ve Türkçe Öğrenimine Karşı } \\
\text { Tutumlarının Karşılaştırmalı Analizi: } \\
\text { Bişkek’teki Üniversite Öğrencilerinin } \\
\text { Vaka Çalışması } \\
\text { 对吉尔吉斯斯坦大学生汉语和土耳其 } \\
\text { 语语言态度的对比分析 }\end{array}$ & Li Yiqi & $\begin{array}{l}\text { Xinjiang Normal } \\
\text { Üniversitesi }\end{array}$ & Y. Lisans & 2016 \\
\hline 10 & $\begin{array}{l}\text { Çince ve Türkçe'deki Deyim ve } \\
\text { Atasözlerinin Karş1laştırılması } \\
\text { 汉语与土耳其语中成语和俗语的对 } \\
\text { 比研究 }\end{array}$ & Aylin Yilmaz & Zhejiang Üniversitesi & Y. Lisans & 2017 \\
\hline 11 & $\begin{array}{l}\text { Hayvan ve Renk İsimleri ile Kurulan } \\
\text { Çince-Türkçe Atasözlerini Karş1laştırma } \\
\text { 汉语和土耳其语动物及颜色类成语对 } \\
\text { 比研究 }\end{array}$ & Fatma Ceren Atay & Jilin Üniversitesi & Y. lisans & 2019 \\
\hline 12 & $\begin{array}{l}\text { Şekil Bakımından Çince Türkçe } \\
\text { Niteleme Sözcüklerini Karşılaştırma ve } \\
\text { Bu Sözcüklerin Nasıl Öğrenilebilirliği } \\
\text { Hakkında Araştırma } \\
\text { 汉语与土耳其语定语类型比较与习 } \\
\text { 得研究 }\end{array}$ & Kübra Demir & $\begin{array}{l}\text { Shanghai Normal } \\
\text { Üniversitesi }\end{array}$ & Y. lisans & 2019 \\
\hline
\end{tabular}

Tablo 7'ye bakıldığında Türkçe üzerine 12 yüksek lisans tezi bulunduğu görülmektedir. Tezlerin tamamı son 14 yıllık sürede yazılmıştır ve hiç doktora tezi bulunmamaktadır. Tezlerden 6'sı Türk yazarlar tarafından yazılırken diğer 6 tez Çinli yazarlar tarafından kaleme alınmıştır. Hâlihazırda 12 üniversitede Türkoloji bölümü bulunduğu dikkate alındığında Çin'de lisansüstü çalışmalara daha çok ihtiyaç duyulduğu söylenebilir. Bu noktada dikkate alınması gereken bir husus da özellikle Türkiye'de Türkoloji üzerine lisansüstü eğitimlerini yapan Çinli araştırmacılardır. Çin'deki üniversitelerde çalışan akademik personelin bir bölümü eğitimlerini Türkiye'de tamamlamışlardır. Lisans ya da lisansüstü eğitimlerini Türkiye'de tamamlayan Çinli araştırmacılar bu araştırmanın konusu dışında kalmaktadır. Bu nedenle burada yalnızca Türkoloji üzerine Çin'de yapılan akademik çalışmalara yer verilmiştir.

g. Türkçe üzerine yazılan makaleler

Tablo 8: Türkçe Üzerine Yazılan Makaleler

\begin{tabular}{|c|l|l|c|}
\hline $\mathbf{N o}$ & Adı & Yazar(lar)I & Yılı \\
\hline $\mathbf{1}$ & $\begin{array}{l}\text { Türkçe, Uygurca ve Kazakça Kelimelerin Karşılaştırılması } \\
\text { 土耳其语、维吾尔语和哈萨克语词汇比较 }\end{array}$ & Gelajiding-Ousıman, Li Shaonian & 1989 \\
\hline $\mathbf{2}$ & $\begin{array}{l}\text { Türkçenin Fonetik Türlerinin Özellikleri } \\
\text { 土耳其语语音类别特点 }\end{array}$ & Cui Chongde & 1993 \\
\hline $\mathbf{3}$ & $\begin{array}{l}\text { Türkçedeki Çekim Ekleri: “-DIk” } \\
\text { 土耳其语构词词缀-dı }\end{array}$ & Ye Shaojun & 1993 \\
\hline $\mathbf{4}$ & $\begin{array}{l}\text { Kazakça ve Türkçe Ünsüz Benzeşmelerinin Özellikleri Ayrıca } \\
\text { Fonetik Benzeşe ve Dil Etkisi Üzerine Bir Araştırma } \\
\text { 哈萨克语土耳其语辅音对应特点—兼论语音对应与语言 } \\
\text { 影响的关系 }\end{array}$ & Wang Yuanxin \\
\hline $\mathbf{5}$ & $\begin{array}{l}\text { Türkçe ve Moğolca Fonetiklerinin Karşılaştırılması } \\
\text { 土耳其语蒙语语音比较 }\end{array}$ & Wu Hugejiletu & 1995 \\
\hline
\end{tabular}




\begin{tabular}{|c|c|c|c|}
\hline 6 & $\begin{array}{l}\text { Kazakça ve Türkçe Yan Yana (anababa) Birleşik Kelimelerin } \\
\text { Morfolojik Düzen Özellikleri } \\
\text { 哈萨克语土耳其语并列复合词词素顺序的特点 }\end{array}$ & Wang Yuanxin & 1996 \\
\hline 7 & $\begin{array}{l}\text { Kazakça ve Türkçe İkilemelerin Oluşması ve Anlamı } \\
\text { 哈萨克语土耳其语变音重叠的方式及其意义 }\end{array}$ & Wang Yuanxin & 1996 \\
\hline 8 & $\begin{array}{l}\text { Modern Türkçedeki Fiillerin Bütünleşik Açıklaması } \\
\text { 现代土耳其语动词一体化描写 }\end{array}$ & Tang Qingguo & 1997 \\
\hline 9 & $\begin{array}{l}\text { Kazakça ve Türkçedeki Bazı Kelimeler Arasındaki } \\
\text { Benzerlikler ve Farklılıklar } \\
\text { 哈萨克语和土耳其语部分词的异同 }\end{array}$ & Jieensi Ahemaiti & 1998 \\
\hline 10 & $\begin{array}{l}\text { Türk Dillerinde Sözcüksel Eğilimler: Modern Uygurca ve } \\
\text { Modern Türkçede “Baş” Kelimesi Örneği } \\
\text { 突厥语族语言的词汇发展趋势——以现代维吾尔语和现代 } \\
\text { 土耳其语的baş一词为例 }\end{array}$ & Maitireyimu-Shayiti & 1999 \\
\hline 11 & $\begin{array}{l}\text { Basında Kullanılan Türkçe'nin Özellikleri ve Çevirme } \\
\text { Yöntemleri } \\
\text { 新闻土耳其语特点及翻译策略 }\end{array}$ & Ding Huijun & 2005 \\
\hline 12 & $\begin{array}{l}\text { Türkçe Birleşik ve Kültürlerarası Kelimelerin Çevirisi: Orhan } \\
\text { Pamuk'un Romanları Örneği } \\
\text { 土耳其语复合词和文化词汇的翻译：以奥尔罕·帕慕克 } \\
\text { 的小说为例 }\end{array}$ & Huang Hui & 2006 \\
\hline 13 & $\begin{array}{l}\text { Türkçe Cümlelerde Zarfların Sıralama Kuralları ve Bilişsel } \\
\text { Özellikleri } \\
\text { 土耳其语句子中副词的排序规则及其认知特点 }\end{array}$ & Wang Yuanxin & 2006 \\
\hline 14 & $\begin{array}{l}\text { Türkçedeki Hal Eklerinin Çinceye Çevirisi Üzerine Bir } \\
\text { Araştırma: Hitit } 1 \text { Ders Kitabı Örneği } \\
\text { 土耳其语格词缀的汉译研究：以《Hitit 1》为例 }\end{array}$ & Zeng Lanya & 2006 \\
\hline 15 & $\begin{array}{l}\text { Türkçedeki Pekiştirme Sözcük Şekilleri } \\
\text { 土耳其语词的强化形式 }\end{array}$ & Peng Jun & 2007 \\
\hline 16 & $\begin{array}{l}\text { Türkçe Çince Cümle Yapılarını Karşılaştırma ve Çevirme } \\
\text { Yöntemleri } \\
\text { 土耳其语汉语句子结构比较及翻译策略 }\end{array}$ & Peng Jun, Ding Huijun & 2010 \\
\hline 17 & $\begin{array}{l}\text { “Olmak" Yardımcı Fiilinin Birleşik Zamanlarındaki Zaman } \\
\text { Anlamları } \\
\text { 助动词 “olmak” 复合时态的时间意义 }\end{array}$ & Ding Huijun & 2011 \\
\hline 18 & $\begin{array}{l}\text { Türkçedeki Çoğul Eki “-ler” İle Çincedeki “men” Eklerinin } \\
\text { Karş1laştırılması } \\
\text { 土耳其语复数词缀 “-ler” 与汉语“们” 的比较 }\end{array}$ & $\begin{array}{l}\text { Li Haiqing, Semine İmge } \\
\text { Azertürk }\end{array}$ & 2011 \\
\hline 19 & $\begin{array}{l}\text { Türkçedeki Hitap Sözleri ve Fonksiyonları } \\
\text { 土耳其语呼语及其功能 }\end{array}$ & Ding Huijun, Peng Jun & 2012 \\
\hline 20 & $\begin{array}{l}\text { Salarca ve Türkçe'nin Telaffuz Karşılaştırması } \\
\text { 撒拉语和土耳其语发音比较 }\end{array}$ & Ma Wei & 2012 \\
\hline 21 & $\begin{array}{l}\text { Saf Türkçe Çizgilerini Aşmak: Orhan Pamuk’un Benim Adım } \\
\text { Kırmızı Romanının Türkçe ve İngilizce Tercümesinin Stilistik } \\
\text { Bir Analizi } \\
\text { 越过纯土耳其语线 : 奥尔罕·帕慕克的小说《我的名字叫 } \\
\text { 红》英译本的修辞性分析 }\end{array}$ & Ji Yaokai & 2012 \\
\hline 22 & $\begin{array}{l}\text { Türkçe Çince Fonetik Sisteminin Karşılaştırmalı Bir Çalışması } \\
\text { 土耳其语汉语语音系统对比研究 }\end{array}$ & Li Xia & 2012 \\
\hline 23 & $\begin{array}{l}\text { Türkçedeki İsim Morfolojisinin Otomatik Analizi İçin Sonlu } \\
\text { Durum Aktarım Ağ1 } \\
\text { 土耳其语名词形态自动分析的有限状态转移网络 }\end{array}$ & Shen Zhixing & 2013 \\
\hline
\end{tabular}




\begin{tabular}{|c|c|c|c|}
\hline 24 & $\begin{array}{l}\text { Türk İsimlerinin Kurallı Çevrilmesi } \\
\text { 土耳其语名词的规则性翻译 }\end{array}$ & Ding Huijun & 2013 \\
\hline 25 & $\begin{array}{l}\text { Türkçede Emir Kipi Olmadan Emir Anlamı Veren İfadeler } \\
\text { 土耳其语中非命令式的祈使表达 }\end{array}$ & Ding Huijun & 2014 \\
\hline 26 & $\begin{array}{l}\text { Türkçedeki Ettirgen Yapının Çincedeki Karşılığ } 1 \\
\text { 土耳其语使动态的汉语对应 }\end{array}$ & Wan Yanjie & 2014 \\
\hline 27 & $\begin{array}{l}\text { Salarca ve Türkçe Kelimelerin Karşılaştırılması Üzerine Bir } \\
\text { Çalışma } \\
\text { 撒拉语和土耳其语词汇比较研究 }\end{array}$ & Ma Wei & 2014 \\
\hline 28 & $\begin{array}{l}\text { Sudan Lehçesindeki Avrupa Dilleri ve Türkçeden Geçen } \\
\text { Kelimeler } \\
\text { 苏丹方言中的欧洲各语言及土耳其语借词 }\end{array}$ & Wei Qirong & 2014 \\
\hline 29 & $\begin{array}{l}\text { Pinokyonun Macerası İsimli Kitabın } 2 \text { Türkçe Çevirisinin } \\
\text { Çeviri Eleştirisi İle Eleştirel Okumanın Önemi } \\
\text { 《皮诺丘历险记》两个土耳其语译本的翻译评述及批判性 } \\
\text { 阅读的重要性 }\end{array}$ & Liu Ying & 2014 \\
\hline 30 & $\begin{array}{l}\text { Türkçe Elektronik Kaynakların Kullanımı } \\
\text { 土耳其语电子文献的使用 }\end{array}$ & Chen Qing & 2014 \\
\hline 31 & $\begin{array}{l}\text { Türkiye Türkçesi Fiillerinin Nomilizasyonlarının Bilişsel } \\
\text { İncelenmesi } \\
\text { 土耳其语动词名词化的认知研究 }\end{array}$ & Ding Huijun & 2015 \\
\hline 32 & $\begin{array}{l}\text { Şema Teorisinden Yola Çıkarak Kırmızı Sorgum Ailesi Türkçe } \\
\text { Baskılarındaki Kültürel Hatalar } \\
\text { 从图式理论看红高粱家族土语译本中的文化误译 }\end{array}$ & Peng Jun & 2015 \\
\hline 33 & $\begin{array}{l}\text { Çincedeki Eklerle Türkçedeki Eklerin Gramer Özelliklerinin } \\
\text { Karş1laştırılması } \\
\text { 汉语词缀与土耳其语词缀语法特点比较 }\end{array}$ & Liu Jun, Semine İmge Azertürk & 2015 \\
\hline 34 & $\begin{array}{l}\text { Çincenin Yaygınlaşmasına Örnek Olarak Türkmenistan'daki } \\
\text { Türkiye Türkçesinin Yaygınlaşması } \\
\text { 土库曼斯坦的土耳其语推广对汉语推广的启示 }\end{array}$ & Li Jinhuan, Li Rui & 2015 \\
\hline 35 & $\begin{array}{l}\text { Çin Yemek İsimlerinin Türkçe Çevirisi } \\
\text { 中国菜名的土耳其语翻译 }\end{array}$ & Liu Wenjun & 2015 \\
\hline 36 & $\begin{array}{l}\text { Türkçe ve Özbekçe Arasındaki Bağlantı ve Farklar Üzerine } \\
\text { Bir Araştırma } \\
\text { 土耳其语和乌兹别克语之间的联系与差异研究 }\end{array}$ & Pang Hui & 2015 \\
\hline 37 & $\begin{array}{l}\text { Çağdaş Uygurca ve Çağdaş Türkçedeki Ekler +1 (X) Q, +1 } \\
(\mathrm{X}) \mathrm{k} \\
\text { 现代维吾尔语和现代土耳其语中的词缀 “ } 1(\mathrm{X}) \mathrm{Q},+1(\mathrm{X}) \mathrm{k} \text { ” }\end{array}$ & Abdulmicet Celili & 2015 \\
\hline 38 & $\begin{array}{l}\text { Türkçe Hece Segmentasyon Yöntemi Üzerine Bir Araştırma } \\
\text { 土耳其语音节划分方法研究 }\end{array}$ & $\begin{array}{l}\text { Abulimiti } \cdot \text { Hujieke, Aizierguli, } \\
\text { Yusupu } \cdot \text { Aibudula }\end{array}$ & 2016 \\
\hline 39 & $\begin{array}{l}\text { Türkçe Zaman Kavramsal Fiilleri Anlambilimsel Perspektiften } \\
\text { Görmek } \\
\text { 从语义场视角看土耳其语时间概念类动词 }\end{array}$ & Shen Zhixing, Li Yunpeng & 2016 \\
\hline 40 & $\begin{array}{l}\text { Türkçe Latin Alfabesi ile Çince Pinyin'in Karşılaştırılması } \\
\text { 土耳其语拉丁字母与汉语拼音比较 }\end{array}$ & Li Haiqing & 2017 \\
\hline 41 & $\begin{array}{l}\text { Kırgızistan'da Türkiye Türkçesinin Yaygınlaşması Üzerine Bir } \\
\text { Araştırma } \\
\text { 土耳其语在吉尔吉斯斯坦的传播现状研究 }\end{array}$ & Chen Jiaojiao & 2017 \\
\hline 42 & $\begin{array}{l}\text { Türkçedeki Ad Aktarması ile Metaforların Etkileşmeleri } \\
\text { 土耳其语中转喻和隐喻的相互影响 }\end{array}$ & Ding Huijun & 2018 \\
\hline 43 & $\begin{array}{l}2017 \text { Yılı Türk Edebiyatına Bir Genel Bakış } \\
\text { 2017年土耳其文学概述 }\end{array}$ & Ding Huijun, Peng Jun & 2018 \\
\hline
\end{tabular}




\begin{tabular}{|c|l|l|c|}
\hline 44 & $\begin{array}{l}\text { Türkçedeki Fiillerin İsme Dönüştüklerindeki Ad Aktarımı } \\
\text { 土耳其语中动词变名词时的转喻 }\end{array}$ & Ding Huijun & 2018 \\
\hline $\mathbf{4 5}$ & $\begin{array}{l}\text { Türkçede İngilizce Kelimelerin Dağılımının ve Kelime } \\
\text { Oluşumunun İncelenmesi } \\
\text { 土耳其语中英语外来词的分布及构词特点浅析 }\end{array}$ & Gong Yingyuan & 2018 \\
\hline $\mathbf{4 6}$ & $\begin{array}{l}\text { Modern Devletin İnşasında Türk Dili Reformu ve Tarihsel } \\
\text { Rolü } \\
\text { 现代国家构建中土耳其语言革命及其历史作用 }\end{array}$ & Yu Fei & 2018 \\
\hline $\mathbf{4 7}$ & $\begin{array}{l}\text { 2018 Y1lı Türk Edebiyatına Genel Bir Bakış } \\
\text { 2018年土耳其文学概述 }\end{array}$ & Ding Huijun, Peng Jun & 2019 \\
\hline $\mathbf{4 8}$ & $\begin{array}{l}\text { Çince ve Türkçedeki Ses Bilgisi ve Öğretim Stratejilerinin } \\
\text { Karş1laştırılması } \\
\text { 汉语和土耳其语语音及教育战略对比 }\end{array}$ & Li Haiqing & 2019 \\
\hline
\end{tabular}

1971 sonrası Çin'de Türkçe üzerine yazılan 48 makale tespit edilmiştir. Tablo 8'de bulunan makaleler incelendiğinde Türkçenin çok farklı boyutlarda ele alındığı görülmektedir. Araştırmaların konuları tematik olarak sınıflandırılacak olunursa 19 makalede Türkçenin bir başka dil ile karşılaştırıldığı görülecektir. Karşılaştırılan dil en fazla Çince olmuştur fakat onula birlikte Kazakça, Özbekçe, Salarca ve Uygurcanın da Türkçe ile farklı yönlerden karşılaştırıldığı görülecektir. Bu durum Çin'de bu dilleri konuşan yurttaşların bulunması ve Çin'in Kazakistan'a ve Moğolistan'a komşu olmasıyla açıklanabilir. Diğer çalışmalara bakıldığında Türkçenin dil bilgisini incelemeye yönelik 14, çeviri çalışmalarına yönelik 9, edebiyatla ilgili 2, Türkçenin diğer ülkelerde yaygınlaşmasına yönelik 2, Türk dil reformuna yönelik 1, Türkçe elektronik kaynakların kullanımına yönelik 1 makalenin bulunduğu görülmektedir. Bu veriler yazılan makalelerde karşılaştırmalı çalışmaların, dil bilgisi ve çeviri incelemelerinin ön plana çıktığını göstermektedir. Ancak Türkoloji çalışmalarının daha bütünsel olarak gelişmesi için edebiyat, metin tahlili, Türkçe öğretim yöntemleri gibi farklı konularda akademik çalışmaların çoğalmasına ihtiyaç vardır.

\section{TARTIŞMA}

Dünyadaki Türkoloji çalışmalarını inceleyen kitaplara ve diğer araştırmalara bakıldığında farklı niteliklerde çalışmalar yapıldığı görülmektedir. Örneğin kimi çalışmalar o bölgedeki Türkologların yaşamlarına ve bilimsel çalışmalarına yönelik bir inceleme yaparken kimi araştırmalar da üniversitelerden hareketle Türkoloji çalışmalarını tasnif etmektedir. Bazı çalışmalarda da konu bağlamında Türkologların hayatları ele alınmıştır. Bu çerçevede öncelikli olarak konuyla ilgili öne çıkan kitaplara bakıldığında Eren (1998) tarafından yazılan Türklük Bilimi Sözlüğü kapsamlı bir eser olarak karşımıza çıkmaktadır. Sözlükte özellikle Avrupalı Türkologların yaşamları ve bilimsel çalışmaları bulunmaktadır. Kononov (2009) ise eserinde Rusya'daki Türk dillerinin araştırılması tarihini incelemiştir. Kırbaç (2012) editörlügüünde hazırlanan eserde ise Balkanlardaki Türkoloji çalışmalarının incelendiği görülmektedir. Eserde bu bölgedeki Türkologlar da tanıtılmıştır. Avrupa'daki Türkoloji çalışmaları üzerine kapsamlı olarak yazılmış daha yakın tarihli diğer bir kitap ise Polonya'da Türkoloji'dir (Emiroğlu, 2017). Bu kitapta Polonyalı Türkologların hayatları ve eserleri bulunmaktadır. Ayrıca bazı üniversitelerde Türkoloji üzerine yazılmış yüksek lisans, doktora ve doçentlik tezleri de yer 
alır. Buran (2018), daha genel çerçevede Türkçeye gönül veren 21 ayrı ülkeden 45 Türkolog’u tanıtmıştır. Yine Buran'a (2019) ait özellikle Orta Asya ülkelerinde cezalandırılan Türkologların yaşamlarını ele alan bir eser daha bulunmaktadır.

Çalışmamızın konusuyla örtüşen, Türkoloji çalışmalarını derleyen son yıllarda yayımlanmış makaleler incelendiğinde Afganistan, Almanya, Amerika Birleşik Devletleri, Bulgaristan, Finlandiya, Fransa, Gürcistan, Hırvatistan, İsveç, İtalya, Japonya, Kıbrıs, Kore, Macaristan, Mısır, Moğolistan, Polonya, Romanya, Rusya gibi ülkelerdeki Türkoloji çalışmaları üzerine çalışıldığı görülmektedir (Albayrak, F., Batchuluun, A. 2019; Attar, A., Sıbgatullina, E., Altınkaynak, E., Sarıkaya, Y. 2012; Çolak, M. 2019; Eltazarov, J. 2015; Erdem, C. 2018; Gül, B. 2006; Gülensoy, T. 2010; İslamoğlu, A. 2010; Kalafat, Ş. 2019; Karakartal, O. 1996; Lee, N., Kim, D. 2016; Musa, B. 2012; Fevzi, F., Cankurt, H. 2013; Ustabulut, M. Y., Kara, K. 2016; Üstünyer, İ. 2013; Yançev, M. 2005). Bu dönemdeki bazı eserler de alana katkı sağlayan isimler üzerinedir (Akar, M. 2019; Berbercan, M. T. 2017; Csató, É., Johanson, L., Zal, Ü. 2014; Çolak, M. 2019b; Duranlı, M. 2018; Emiroğlu, Ö. 2012; Temir, A. 1991; Yusupov, F. 2017). Genel anlamda yurt dışında yürütülen Türkoloji çalışmalarını derleyen çalışmaların, o ülkede Türklük bilimi üzerine meydana gelmiş her türlü çalışmayı ve çalışmaları yürüten önemli Türkologları incelediği görülmektedir. Bu bağlamda bu çalışmada da Çin'deki üniversitelerde yürütülen Türkçe öğretim çalışmalarının durumu, Türkçeden Çinceye çevrilmiş edebi eserler, Türkçe öğretimi üzerine yazılmış öğretim setleri ve Çin'de yazılmış makale, yüksek lisans ve doktora tezleri incelenmiştir. Bu kapsamda Çin'de Türkoloji çalışmaları kapsamlı bir şekilde ele alınmaya çalışılmıştır. Fakat bu çalışma tek başına Çin'deki Türkoloji çalışmalarını betimlemek için yeterli olmayacaktır. Öyle ki Çin'deki Türkoloji çalışmalarını gün yüzüne çıkartmak için gerek tarihi ve dönemsel olarak gerekse Çinli Türkologlar perspektifinden çok daha kapsamlı çalışmalar gerekmektedir.

\section{SONUÇ VE ÖNERILER}

Çin Halk Cumhuriyeti'nde akademik anlamda Türkoloji çalışmalarının 1985 yılında Pekin Uluslararası Çalışmalar Üniversitesi’nde açılan Türkçe bölümü ile başladığı görülmektedir. Geçen 35 yılda Çin'de bulunan Türkoloji bölümü sayısı 12'ye ulaşmıştır. Burada dikkat çeken nokta açılan bölümlerin iki ülke arasındaki diplomatik ve ekonomik ilişkilerdeki gelişmelere paralel olarak değişmesidir. Türkoloji bölümleri yıl aralıklarına göre incelenecek olursa 1985-2000 yıllarında yalnızca 1 bölümün, 2000-2010 yıllarında 2 bölümün, 2010-2019 yıllarında 12 bölümün faaliyet gösterdiği görülecektir. Bölümlerin birçoğunun yakın tarihte açılmış olması Çin'de Türkçeye ve Türkiye'ye karşı bir ilginin olduğunu göstermekle birlikte bölümlerin çoğunun akademik anlamda bir olgunluğa ulaşmadığını da göstermektedir. Çin'de bulunan Türkoloji bölümlerinin Türkiye'deki eşdeğer bölüm ya da ilgili kurumlarla yapacağ iş birlikleri bölümlerin akademik anlamda olgunlaşmasına katkı sağlayacağı gibi akademisyen ve öğrencilerin Türkiye ile bağını da güçlendirecektir. 
Türkoloji bölümlerinin akademik anlamda ihtiyaçlarından biri de yetişmiş akademik personeldir. Sadece 1 üniversitede profesör ve 2 üniversitede 3 doçent unvanına sahip akademik personel bulunmaktadır. Çin genelinde bulunan 37 akademik personelin 33'ü öğretim görevlisi ya da asistan unvanıyla görev yapmaktadır. Bölümlerde bulunan asistan ve öğretim görevlilerinin akademik çalışmalara teşvik edilmesi ile bölümlerin akademik yönleri güçlendirilecektir. Bu bağlamda Türkiye'deki üniversite ve kurumlarla yapılacak akademik personel değişim programlarının uygulanması bu alana katkı sağlayabilir.

1985 yılından bu yana Türkoloji bölümlerinden 316'dan fazla öğrencinin mezun olduğu, aktif olarak 255 öğrencinin öğrenimine devam ettiği tespit edilmiştir. Önümüzdeki yıllarda Türkoloji bölümlerinde öğrenim gören ve bu bölümlerden mezun olan öğrenci sayısında ciddi artış yaşanacağı görülmektedir. Sayılarının artması öngörülen öğrencilerin Türkiye’yi doğru tanıyabilmeleri ve Türkoloji alanına katkı sağlayabilmeleri amacıyla Türkiye'deki ilgili bakanlık ve üniversiteler tarafından bu bölümlere yönelik projeler hayata geçirilebilir.

1971 yılından bu yana yalnızca 25 Türkçe eserin Çinceye çevrildiği, bu eserlerden de 13 'ünün tek bir yazara ait olduğu görülmektedir. Bu durum Türkiye'ye ait yazılı kaynakların Çin'de tanınmadığını ya da ilgi görmediğini göstermektedir. Türk Edebiyatına yönelik çeviri ve tanıtım çalışmalarının Türkiye tarafından desteklenmesi iki ülke arasındaki kültürel ilişkilerin geliştirilmesine katkı sağlayacaktır.

Türkoloji bölümlerindeki akademik eksikliğin bir diğer göstergesi de Türkoloji bölümlerinde kullanılan Türkçe öğretim kaynaklarının yeterli olmaması hatta bazı beceri alanlarına yönelik kaynakların bulunmamasıdır. Aynı şekilde Türkoloji bölümü öğrencilerinin alan eğitiminde yararlanacağ 1 Çince yazılmış Türk tarihi, edebiyatı, kültürü, sanatı, toplum hayatı ve Osmanlı Türkçesi gibi kaynakların da eksik olmasıdır. Bu alanda çalışan uzmanların bireysel çabaları ile kaynaklar hazırlanmaktadır ancak Türkiye'den ilgili kurum ve üniversitelerin belirlenecek ihtiyaçlar doğrultusunda sağlayacağı destekler ile bu alandaki kaynak sıkıntısı kısa zamanda çözüme kavuşturulabilir.

Akademik göstergelerden biri de hiç şüphe yok ki yazılan makale, yüksek lisans ve doktora tez çalışmalarıdır. Bu anlamda 1971 yılından bu yana Çin'de Türkçe üzerine yazılan makale sayısı 48'dir. Yazılan makalelerin konu dağılımı ise alanı kapsayıcı nitelikte değildir. Yine yazılan yüksek lisans ve doktora tez çalışmalarının bölüm sayısına oranla düşük bir seviyede kaldığı görülmektedir.

Sonuç olarak Türkiye ve Çin arasında yakın geçmişe dayanan ilişkiler hızla gelişmektedir. İlişkilerin hızlı gelişimi nicelik bakımından bazı rakamların hızla artmasını sağlamaktadır ancak niteliksel gelişmelerin sayısal değişimi yakalayamadığı görülmektedir. Bu nedenle Türkiye ve Çin arasında Türkoloji anlamında üniversiteler arası, akademisyenler arası ilişkilerin geliştirilmesi bu alanda ihtiyaç duyulan niteliksel gelişmelere katkı sağlayacaktır. Yine aynı şekilde Yunus Emre Enstitüsü (YEE), Yurt Dışı Türkler ve Akraba Topluluklar Başkanlığı (YTB), Türk İşbirliği ve Koordinasyon Ajansı Başkanlığı (TİKA) gibi ilgili Türk devlet 
kurumları tarafından verilen destekler ve hayata geçirilecek projeler ile Çin'deki Türkoloji çalışmalarına nitel katkılar sağlanacaktır. Türkiye tarafından Çin'deki Türkoloji çalışmalarının desteklenmesinin iki ülke arasındaki ilişkileri geliştirmeye katkı sağlayacağı gibi Çin tarafından hayata geçirilmek istenen "Bir Yol Bir Kuşak" projesine de dolaylı yönden katkı sağlayacak olması da göz önünde bulundurulmalıdır.

Hakem Değerlendirmesi: Dış bağımsız.

Çıkar Çatışması: Yazarlar çıkar çatışması bildirmemiştir.

Finansal Destek: Yazarlar bu çalışma için finansal destek almadığını beyan etmiştir.

Peer-review: Externally peer-reviewed.

Conflict of Interest: The authors have no conflict of interest to declare.

Grant Support: The authors declared that this study has received no financial support.

\section{KAYNAKÇA/REFERENCES}

Akar, M. (2019). Türklük bilimine emek verenler-1 prof. Bill Hickman ve the story of Joseph'i. Aydın Türklük Bilgisi, 5(2), 149-154.

Albayrak, F. ve Batchuluun, A. (2019). Moğolistan'da Türkiye Türkçesi- Moğolca üzerine yapılan çalışmalar ve Türkçe öğretimi. Asya Araştırmaları Uluslararası Sosyal Bilimler Dergisi, 3(1), 131-156.

Ankara Üniversitesi, (2017). Sinoloji anabilim dal1. http://www.dtcf.ankara.edu.tr/dogu-dilleri-veedebiyatlari-bolumu/sinoloji-anabilim-dali/ 11.12.2019 tarihinde erişilmiştir.

Attar, A., Sibgatullina, E., Altınkaynak, E. ve Sarıkaya, Y. (2012). Türk Filolojisi ile ilgili Rusya bilimler akademisindeki tezler üzerine bir katalog çalışması (geçmişten günümüze Rusya'da Karadeniz ve Türkoloji ile ilgili tezler bibliyografyası ve bunların özetlerinin Türkiye Türkçesine çevrilmesi projesi). Karadeniz Uluslararası Bilimsel Dergi, 1(15), 33-89.

Berbercan, M. T. (2017). İsveç Türkolojisinden iki bilgin: Gustaf Raquette ve Gunnar Jarring. Uluslararası Uygur Araştırmaları Dergisi, (10), 42-54.

BİK. (2019). Uzakdoğulu turistin Türkiye’ye ilgisi artıyor. BIKK. https://www.bik.gov.tr/uzak-doguluturistin-turkiyeye-ilgisi-artiyor/ 15.11.2019 tarihinde erişilmiştir.

Buran, A. (Ed.) (2018). Türk diline gönül verenler yabancı Türkologlar. Ankara: Akçağ.

Buran, A. (2019). Kurşunlanan Türkoloji. Ankara: Akçağ Yayınları.

Csató, É., Johanson, L. ve Zal, Ü. (2014). Profesör Walter Björkman’ın mirası. Türkbilig, (27), 137-154.

Çolak, M. (2019). Macar arşiv belgelerinin ışı̆̆ında I. dünya savaşı sırasında Avusturya-Macaristan topraklarında bulunan Tatar esir kamplarında yaşam, Türkoloji çalışmaları ve Ignác Kúnos (19151918). Türk Dili Araştırmalarl Yıllı̆̆l - Belleten, (67), 231-256.

Çolak, M. (2019). Macar Türkolog Vámbéry'nin Türkistan seyahatinde “büyük oyun” un izleri orijinal fotoğraflarla birlikte. Selçuk Üniversitesi Türkiyat Araştırmaları Dergisi, (45), 13-27.

Dirican, S. ve Özdemir, Ö. (2019). Türkiye'de Çin hakkında yapılan akademik çalışmaların incelenmesi. Doğu Asya Araştırmaları Dergisi, 2(2), 110-138.

Duranlı, M. (2018). Osıp Senkovskıy’ın Rus Türkolojisinin gelişimine katkısı. Türk Dünyası Dil ve Edebiyat Dergisi, (45), 77-91. 
Duran, A. E. (2019). Ticarette Çin Rüzgarı. Ekonomist, sayı: 2019/50, 18-25.

Eltazarov, J. (2015). Japonya'da Türkçenin araştırılması ve öğretimi meseleleri. Akademik Tarih ve Düşünce Dergisi, 2, 65-79.

Emiroğlu, Ö. (2012). Polonyalı Türkolog Malgorzata Labecka-Koecherowa (1917-2011). Türk Dünyası Dil ve Edebiyat Dergisi, (33).

Emiroğlu, Ö. (2017). Polonya'da Türkoloji. Ankara: Türk Dil Kurumu Yayınlar1.

Erdem, C. (2018). Hırvatistan örneğinde balkan coğrafyasına ait bir Türk dili ve edebiyatı öğretimi kaynakçası. Türkbilig, (35), 191-198.

Eren, H. (1998). Türklük bilimi sözlüğ̈̈ I. yabancı Türkologlar. Ankara: Türk Dil Kurumu Yayınlar1.

Ergin, M. (2011). Orhun Abideleri (45.bs). İstanbul: Boğaziçi Yayınları.

Fevzi, F. ve Cankurt, H. (2013). Afganistan'da Türkoloji ve Türkçe çalışmaları hakkında bir araştırma. Celal Bayar Üniversitesi Sosyal Bilimler Dergisi, 11(2), 493-503.

Gül, B. (2006). Almanya'da Türkoloji çalışmaları. Türkbilig, (11), 56-117.

Gülensoy, T. (2010). Kıbrıs’ta Türkoloji çalışmaları ve Mustafa Gökçeoğlu. Motif Akademi Halkbilimi Dergisi, 3(5), 214-216.

İnan, A. (2017). Türkoloji ders notlart. Ankara: Altınordu Yayınları.

İnayet, A. (2006). Doğrudan ve dolaylı olarak Çinceye geçen Türkçe kelimeler üzerine. Türk Dünyası Incelemeleri Dergisi, 6(1), 81-99.

İslamoğlu, A. (2010). Mısır üniversitelerinde Türkoloji çalışmaları. Hitit Üniversitesi İlahiyat Fakültesi Dergisi, 9(18), 143-171.

Kalafat, Ş. (2019). "Treasury” of a French Turcologist: Jean Deny’s unpublished Turkish dictionary. Türkbilig, (37), 71-89.

Karaağaç, G. (2015). Türkçenin alıntılar sözlüğü. Ankara: Akçă̆ Yayınları.

Karakartal, O. (1996). Başlangıcından günümüze genel bir bakışla İtalya’da Türkoloji çalışmaları. Türk Dili Araştırmaları Yıllı̆̆l-Belleten, 42, 253-298.

Kırbaç, S.(Ed.). (2012). Balkan Türkoloji tarihçesi ve Balkan Türkologları. Ankara: T.C. Kültür ve Turizm Bakanlığı.

Kononov, A. N. (2009). Rusya'da Türk dillerinin araştırılması tarihi. (K. V. Nerimanoğlu, Çev.). Ankara: Türk Dil Kurumu.

Lee, N. ve Kim, D. (2016). Trends in Turkish studies in Korea. Bilig, (77), 271-293.

Linghu, D. (2011). Zhou Shu. Shanghai: Zhonghuo Shuju.

Ministry of Education The People's Republic of China. (2020). Statistical report on international students in China for 2018.http://en.moe.gov.cn/news/press_releases/201904/t20190418_378586.html 27.06.2020 tarihinde erişilmiştir.

Musa, B. (2012). Finlandiya Türkologları ve Finlandiya'da Türkoloji çalışmaları bibliyografyası. Türklük Bilimi Araştırmaları, (32), 221-245.

Sarıtaş, E. (2010). Türkiye'de akademik Çince çeviriler ve sorunlar. Şarkiyat Mecmuası, (17) 85-106.

TDK, (2005). Büyük Türkçe sözlük. Ankara: TDK Yayınları.

Temir, A. (1991). Türkoloji Tarihinde Wilhelm Radloff Devri. Ankara: TDK Yayınları

Türkiye Cumhuriyeti Dışişleri Bakanlığı. (2020). Çin Halk Cumhuriyeti. http://www.mfa.gov.tr/sub. tr.mfa?7f3de9f9-4045-4e42-a8d8-6dc8c4089450. 13.04.2020 tarihinde erişilmiştir. 
Ustabulut, M. Y. ve Kara, K. (2016). Romanya'da Türk dili tarihi ve Dobruca'daki (Köstence) Türkoloji eğitimi. Aydın Tömer Dil Dergisi, 1(2), 1-16.

Üstünyer, İ. (2013). Gürcistan'da Türkoloji. Tarih Dergisi, (54), 221-229.

Yançev, M. (2005). Bulgaristan Türkoloji 50 yaşını doldurdu. Türk Dünyası Dil ve Edebiyat Dergisi, (20).

Yıldırım, A. ve Şimşek, H. (2013). Sosyal bilimlerde nitel araştırma yöntemleri. Ankara: Seçkin Yayıncılık.

YÖK, (2019). YÖK Lisans Atlası. https://yokatlas.yok.gov.tr/lisans-anasayfa.php 14.01.2020 tarihinde erişilmiştir.

YÖK, (2020). Yükseköğretim bilgi yönetim sistemi. https://istatistik.yok.gov.tr/ 14.01.2020 tarihinde erişilmiştir.

Yusupov, F. (2017). W. Radloff ve Türk dünyası. Uluslararası Türk Lehçe Araştırmaları Dergisi (TÜRKLAD), $1(1), 12-23$. 